\title{
DISCOVERY PROCEDURE AND PRACTICE: RECENT DEVELOPMENTS
}

\author{
GLEN H. POELMAN ${ }^{*}$
}

The article reviews significant recent developments in civil procedure in Alberta. With respect to the examination of documents, the author looks at recent cases dealing with: "possession or power"; whether the cost of producing affects a party's obligation to produce; the consequences of failing to produce a document; the description of privileged documents; and what do and do not qualify as privileged documents.

In terms of the examination of witnesses, the author surveys recent cases which deal with: whom may be examined (including the cases of corporate solicitors, spouses, advisors and consultants): compelling examination of witnesses outside the province; the scope of questioning allowed in discovery; the duty to inform; and the use of discovery evidence at trial, especially for the case of employees.
Le présent article se penche sur l'évolution récente de la procédure civile en Alberta en ce qui touche les témoins. Dans le cadre de la loi régissant l'examen de documents, l'auteur étudie des cas récents et étudie notamment la notion de pouvoir; si les coûts liés à la production de documents auraient une incidence sur l'obligation de les soumettre, les conséquences qu'entraine le manquement à cette obligation, la description des documents privilégiés et ce qui peut et ne peut pas être décrit comme tel.

En ce qui touche l'interrogation des témoins, l'auteur examine qui peut être interrogé 6 compris les avocats de sociétés, les conjoints, conseillers et experts-conseils), les mesures assurant la comparution des témoins venant de l'extérieur de la province, les questions permises au cours de l'interrogatoire préalable, l'obligation d'informer ou de divulguer, et l'utilisation au procès des preuves recueillies pendant l'interrogatoire préalable, surtout dans le cas d'employés.

\section{TABLE OF CONTENTS}

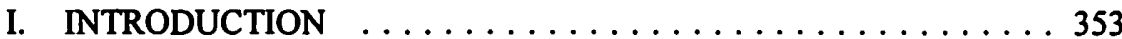

II. DISCOVERY BY PRODUCTION OF DOCUMENTS . . . . . 353

A. EXTENT OF OBLIGATION TO PRODUCE

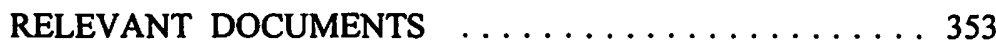

B. SIGNIFICANCE OF PRODUCTION $\ldots \ldots \ldots \ldots \ldots . .355$

C. DESCRIPTION OF PRIVILEGED DOCUMENTS . . . . 356

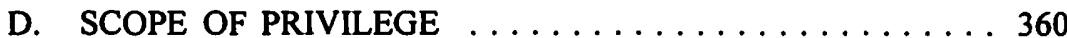

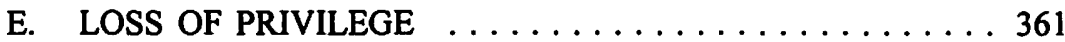

III. DISCOVERY BY EXAMINATION OF WITNESSES $\ldots \ldots \ldots 361$

A. WHO MAY BE EXAMINED $\ldots \ldots \ldots \ldots \ldots \ldots \ldots \ldots$

B. COMPELLING ATTENDANCE $\ldots \ldots \ldots \ldots \ldots \ldots 363$

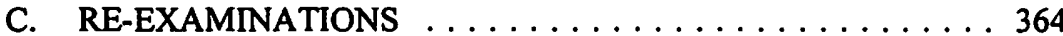

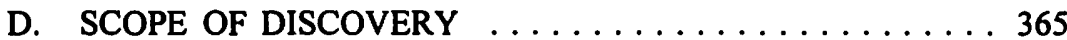

E. DUTY TO INFORM AND UNDERTAKINGS . . . . . 367

F. USE OF DISCOVERY EVIDENCE

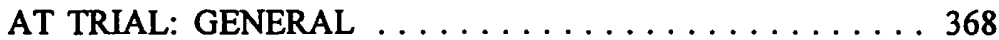

G. USE OF DISCOVERY EVIDENCE

AT TRIAL: EMPLOYEES . . . . . . . . . . . . . . . . 370 


\section{INTRODUCTION}

The following is a review of the principal developments observed in the authorities which affect discovery practice in Alberta, in relation both to documents and witnesses. The primary focus therefore is on decisions from the Alberta courts, although reference is also made to some cases of note from other provinces. It will be apparent that no effort has been made to comment on all of the Alberta cases concerning the discovery process, but rather, attention has been given to those cases considered to be of particular interest to practitioners of civil litigation.

The article is organized under the two main subjects of production of documents and examination of witnesses. It is important to recognize, however, that many of the principles governing the discovery process apply to both subject areas.

\section{DISCOVERY BY PRODUCTION OF DOCUMENTS}

\section{A. EXTENT OF OBLIGATION TO PRODUCE RELEVANT DOCUMENTS}

Rules 186 and 188 of the Alberta Rules of Court' require parties to an action to "discover by affidavit" all documents in their possession or power relating to the matters at issue. There have often been questions about whether the notes and records of a medical practitioner are within the "possession or power" of the patient. This is properly addressed when the affidavit of documents is first prepared, but more typically arises when a party being examined for discovery is asked to undertake to obtain and produce his doctor's chart. An Ontario court recently found the authorities to be in conflict on whether a party was obliged to request such documents of his doctor, or if the examining party should be left to his remedies under the provision for seeking documents from non-parties (in Alberta, r. 209(1)). The weight of authority seemed to establish that the doctor's files were not in the "possession, control or power" of the patient, who had no entitlement to them. However, it was found that "the established practice is to require the patient to authorize and request the doctor to produce the notes and records" and an order was granted to that effect. ${ }^{2}$

The Ontario ruling is consistent with the earlier Alberta case of Price v. Labossiere, ${ }^{3}$ where Sinclair J. held, without determining the legal entitlement of a patient to treatment notes, that a physician's "notes and records ... are in the 'power' of the plaintiff in the sense that it would be reasonable for her to request them from her physician." If the documents were not delivered following such a request, the defendant could then apply for their production as against the physician directly under r. 209. 
The practice of requiring a plaintiff to request production of medical information from treating professionals may be affected by the Court of Appeal's decision in Wright v. Schultz. ${ }^{5}$ The plaintiff's action was based on a motor vehicle accident in which he had sustained severe brain injuries. One of the issues before the Court of Appeal was whether the plaintiff was required to answer questions about what he was told by others about the accident, events which his injuries prevented him from personally recalling. Hetherington J.A. found that he was required to provide information he had received from others, but was not obliged to seek information except from those over whom he had control. Hetherington J.A. noted that "an individual has no control over his employer, someone who has performed medical services for him, or employees at a school that he attends or has attended."6

It does not seem from the reported decision that requests to obtain medical records were expressly at issue. However, the brief statement of Hetherington J.A., quoted above, and her finding that an individual was not required to make inquiries of those over whom he has no control, might suggest that a plaintiff is not obliged to provide medical records in the possession of his treating professionals. On the other hand, it must be expected that the court would find it more reasonable to require plaintiffs to request copies of file materials from professionals who have been paid for their services, than to compel the plaintiff to actually make inquiries of the professionals (or others) for the purpose of enabling the plaintiff to give discovery evidence. It seems clear that Wright v. Schultz dealt primarily with "questions about what [the plaintiff] has been told by others about the accident and about other relevant matters." Accordingly, it seems unlikely that the practice established by Price v. Labossiere and other authorities will be reversed by Wright v. Schultz.

Even where the documents may be accessible to a party, issues sometimes arise over the cost of obtaining them - again, typically when a request for undertaking is made at examination for discovery. In Labrosse v. Eli Markovitch Professional Corp., another case involving a request that a party produce documents from treating professionals, Waller M.C. noted that "this question arises frequently in practise and a review of the current authorities may be useful to the profession." ${ }^{9}$ He disagreed with the approach of an Ontario court which obliged the defendant to reimburse the plaintiff for charges related to obtaining documents requested by the defendant. In reviewing the authorities, Waller M.C. observed the movement towards greater disclosure in the discovery process, and found that the cost of obtaining a document was irrelevant to a party's obligation to make production. Some of the authorities quoted gave the rationale for this approach: there are costs associated with litigation in general, and the discovery process in particular; and a party cannot escape his obligation to produce documents on the basis of cost. The provision for recovery of costs at the conclusion 
of an action provides sufficient protection against production costs as well. However, Waller M.C. was prepared to recognize the possibility of exceptions: "in circumstances where a plaintiff is impoverished and has an action which sounds well founded, the Court might extend the same principles governing a security for costs application to the production of documents." 10

We will comment below on the dispute which frequently arises over the description of privileged documents in an affidavit of documents. It is more unusual to see a dispute over the description required of producible documents, but this issue arose before Kent J. in Roy v. Krilow." The plaintiff had described his producible documents simply by referring to "documents mechanically numbered 000001 to $000020 .{ }^{\prime \prime 2}$ Kent J. referred to earlier authority which appeared to approve of such descriptions in the interests of avoiding oppressively lengthy affidavits, but she understandably saw the need for some brief description of documents in modern litigation for the convenience of opposite parties. She suggested that documents be identified "by date and by type (letter, drawing, photograph and so on)." ${ }^{13}$

\section{B. SIGNIFICANCE OF PRODUCTION}

There are effects of production and non-production of documents which go beyond the simple fact of disclosure to opposite parties. Many of the implications are contained in the applicable rules.

A party served with an affidavit on production is deemed to admit that the described documents were written, signed or executed as purported, that copies are true copies, and that in the case of letters, they were sent and received, unless a notice of denial is served within thirty days of receipt of the affidavit. ${ }^{14}$ A party serving the affidavit is deemed to make the same admissions ${ }^{15}$ and is deemed to have been served with a notice requiring him to produce the documents at subsequent proceedings. ${ }^{16}$ The party serving the affidavit may not use any document in evidence other than those included in the affidavit, unless the court is satisfied of sufficient cause for omission of nonproduction. ${ }^{17}$ Because the principles of "relevance" at the discovery stage are broader than at trial, neither party is deemed to admit relevancy or admissibility of documents produced. $^{18}$

More particular effects appear from time to time in the authorities. In one recent case, the parties had agreed upon a partial settlement of an action before trial, which

Ibid. at 207-08. In this connection, he referred to decisions regarding exceptions the court will sometimes make in the case of "needy litigants."

(1995), 29 Alta. L.R. (3d) 272 (Q.B.).

Ibid. at 272.

Ibid. at 274-75.

Alberta Rules of Court, supra note 1, r. 190(1) and (2).

lbid., r. 190(3).

Ibid., r. 190(4).

Ibid., r. 195(1).

Ibid., rr. 190(1) and 198. 
removed the dispute as it related to certain damages issues. An affidavit on production had been filed by the defendant prior to the settlement. The plaintiff later discovered documents which were relevant and should have been produced by the defendant, and successfully obtained an order requiring production. At a subsequent hearing, the Court found that the defendant's failure to include potentially relevant documents in the affidavit gave the Court the ability to set aside the settlement agreement, and found that evidence on the settled issues could be led at trial. ${ }^{19}$

The content of an affidavit on production will also be important in instances where the mere possession of a document by a party at a material time may be important evidence, so that the document could be accepted at trial as an exhibit simply upon proof that it was in the party's possession. Inclusion of documents in the party's affidavit on production may be the only evidence necessary to successfully tender the document as an exhibit. ${ }^{20}$

\section{DESCRIPTION OF PRIVILEGED DOCUMENTS}

Parties have an obligation to include within the scope of their affidavits on production all relevant documents within their possession or power, including those over which a claim for privilege is made. Privileged documents, which need not be produced to opposite parties, generally fall into three categories: documents prepared in contemplation of litigation and for the dominant purpose of instructing counsel; documents prepared as part of or describing communications between a solicitor and client; and communication between parties and their representatives with respect to settlement ("without prejudice" communications). In fact, the first two categories are often described as one "solicitor-client privilege" category, embracing both the litigation privilege and the "legal advice" privilege. ${ }^{21}$

The fact that parties to a lawsuit have the obligation to "discover by affidavit" even their privileged documents (but need not actually disclose them) leads to disputes about the degree of particularity required for the description of privileged documents in an affidavit on production. While we do not have clear authority from the Alberta Court of Appeal on this point, until recently, courts seemed to accept the proposition that there must be a means of identifying the documents for which privilege is claimed, but opposite parties are not entitled to a description of the documents. Under this approach, information such as the type of document, date, author and recipient need not be given. According to Quinn M.C., "it appears that the most effective way of describing documents without revealing anything about the contents of the documents is to use a system of numbering and initialling." 22

\footnotetext{
19 Saballoy Inc. v. Techno Genia S.A. (1993), 9 Alta. L.R. (3d) 179 (Q.B.).

20 Dassen Gold Resources Lid. v. Royal Bank of Canada (1993), 138 A.R. 275 (Q.B.).

21 Brosseau v. Bhimji (1994), 153 A.R. 21 (Master); and Metropolitan Trust Co. of Canada v. 337807 Alberta Lid. (1994), 154 A.R. 58 (Master).

22

Dorchak v. Krupka (1994), 160 A.R. 51 (Master). Master Quinn made a similar ruling in MacQuarrie v. Bong (1995), 28 Alta. L.R. (3d) 142 at 144-45 (Master). For a more complete review of the authorities by Master Quinn, see Woreta v. Chang (1994), 156 A.R. 49 (Master). For review and commentary of earlier authorities and the issues, see also "Civil Procedure and
} 
The traditional practice reflected the view that the purpose of including privileged documents in an affidavit on production is not to enable another party to evaluate and test the claim for privilege, but only to enable the court to order specific documents to be produced for inspection if privilege is challenged. This was the approach of Cotton L.J. in Taylor v. Batten, who found acceptable the following description: "The documents referred to in paragraph 2 of my former affidavit are numbered 50-76 inclusive, and are tied up in a bundle marked with the letter $\mathrm{A}$ and initialled by me."123

\section{His reasons were as follows:}

But it is said that the plaintiffs are entitled to be put in such a position as to test the truth of the affidavit by the description of the documents. That, however, is in our opinion, erroneous. The only object of the affidavit is to enable the court to order the documents to be produced, if it thinks fit to make an order to that effect; and if words are used which, if true, protect the documents, no further particularity is necessary than in the case of documents for which protection is not claimed. ${ }^{24}$

Recent trends in the authorities suggest that the Alberta courts are moving toward an approach which recognizes the value of greater description of privileged documents, in the interest of enabling opposite parties and the courts to test the validity of privilege claims. The Court of Appeal seemed to expect a higher level of disclosure when it addressed Crown privilege (or public interest immunity) claims in Pocklington Foods Inc. v. Alberta (Provincial Treasurer). ${ }^{25}$ In reviewing the facts, Côté J.A. noted that the Crown had filed a detailed certificate describing classes of documents and the reasons why privilege was claimed for them, and later filed a detailed list giving date, author, addressee, type of document and some description of content of each of the documents. The Queen's Bench judge had previously examined all the documents, and made determinations with respect to some of them. There were forty-one documents on which he was unable to decide; he directed that the Crown show them to three of the opposing lawyers to enable them to make more detailed submissions, and directed that they give undertakings not to disclose the documents further. (The lawyers apparently had instructions enabling them to give such undertakings.)

Côté J.A. observed that privilege is a substantive rule, and it "means the power (or immunity) to keep a document secret and not have to reveal it to anyone." ${ }^{26}$ Inspection by the court is "theoretically wrong" but is allowed for pragmatic reasons, because in practice it can do no harm. However, to allow an opposing solicitor ("the enemy's general") to review documents to aid the court in its inspection process leads to a

Practice: Recent Developments" (1992) 30 Alta. L. Rev. 1100 at 1111-13.

(1878), 4 Q.B.D. 85 at 87 (C.A.).

Ibid. at 88. (It appears from the decision that for producible documents, numbered and initialled bundles were considered acceptable.) For a different approach, see Brugge v. British Columbia (Workers' Compensation Board) (1991), 49 C.P.C. (2d) 51 (B.C.S.C.M.), which also contains a useful annotation criticizing the decision and collecting some of the relevant cases.

[1993] 5 W.W.R. 710 (Alta. C.A.) [hereinafter Pocklington Foods].

Ibid. at 717. 
strong likelihood of harm and actual harm in many cases, and should not be allowed even where undertakings of the nature ordered in this case were given. ${ }^{27}$

While recognizing the difficulty of the judge's task, it was noted that more practical assistance was available in the Pocklington Foods ${ }^{28}$ case. Counsel for the Crown had said during argument at the Court of Appeal that he perhaps had not given sufficient description of the forty-one documents to the opposing party, and volunteered to give more details. This would enable the court to receive more helpful argument on the documents.

Côté J.A. then observed that there is a requirement that parties depose in their affidavits to facts founding privilege, and that the onus of proof in establishing privilege is on the party claiming it. He observed in part as follows:

[M]any documents contain no clue whatever as to when or why they were created. By themselves, they do nothing to prove or disprove privilege. That is why the law has always called for affidavits of documents, or affidavits or certificates by Ministers, giving the facts founding privilege.... Where there is not enough outside evidence of privilege, the court does not even get to inspection. Inspection only arises where there is already enough proof of privilege, by an adequate affidavit or certificate by a Minister. The onus of proof is on the party claiming privilege. So if she does not file a sufficient affidavit or certificate, no inspection is necessary. The document is simply producible for want of evidence that it is not.

Why do judges sometimes inspect the documents? Only to guard against the possibility that the affidavit or other evidence for privilege is not accurate, whether because of clerical error, dishonesty, or misunderstanding of the law.

But often the wording of a document itself offers no real guidance as to privilege. The result then is not a mystery. It simply means that the judge ruling on privilege must rely upon the affidavit or certificate claiming privilege, and on any other outside evidence by either side. The judge's inspection is like an external physical examination by a physician. It is a useful check. But it is not a substitute for a careful history or lab test, and the external sights and sounds will often be inconclusive. ${ }^{29}$

In the result, the Court of Appeal ordered the Crown to provide the additional information which it had offered during argument, and returned the matter to Queen's Bench for further argument.

It seems implicit from Côte J.A.'s reasons that he found it proper for the Crown to volunteer additional information respecting the document for which privilege was claimed, and incorporated a direction to that effect in his judgment. He also emphasized the onus on a party claiming privilege to include sufficient facts in its affidavit of 
documents to establish the validity of privilege. In the absence of sufficient factual foundation, there would be an order for production. The court will not engage in an inspection unless there is, in the first place, sufficient affidavit evidence to establish a prima facie claim of privilege.

These observations seem to be confirmed by comments of the Court of Appeal in Syncrude Canada Ltd. v. Babcock \& Wilcox Canada Ltd., ${ }^{30}$ where the Court dealt with this point briefly:

The first challenge is to the adequacy of the affidavit evidence saying the documents were created for privileged purposes. The appellant objects to bald statements on the subject by a lay deponent, and to additional hearsay on the same subject. On this interlocutory application we cannot see that either is a valid objection. Those passages in the relevant affidavit are clear. What is more, the appellant filed an affidavit which contains a long, detailed list of the documents in question. A number of the descriptions there do much to support the suggestion of privilege, given the descriptions of contents, or the authors and addressees, or the dates. And none do anything to cast doubt on that claim. ${ }^{31}$

While there is no suggestion that the detail given by the deponent was required, the detail was certainly relied upon by the Court in its reasons.

The trend toward greater disclosure of the nature of the document over which privilege is claimed is also evident in Roy v. Krilow, where Kent J. based her decision upon the earlier case of Hamilton v. Alberta (Minister of Public Works, Supply \& Services). ${ }^{32}$ She interpreted that decision as holding that privileged documents must generally be numbered, described by their nature, date, maker and recipient, and observed that this was consistent with common sense. She believed this was important, because without such information, "neither the opposite party nor the Court can determine whether privilege has been properly claimed if nothing is known of the document. ${ }^{133}$ However, Kent $\mathrm{J}$. was prepared to recognize the need to be flexible, in order to provide adequate protection of privileged information which might be disclosed by such a description: "It may be that for some documents in some cases some of the information that I have itemized will itself reveal privileged information. In such cases, the particular information need not be disclosed, subject to review by the Court. ${ }^{\text {134 }}$

It is interesting to compare the approaches taken, implicitly or expressly, in Pocklington Foods, Syncrude Canada and Roy v. Krilow, with the often-cited approach of Cotton L.J. in Taylor v. Batten. It is also significant to note that Côte J.A. apparently approved of Cotton L.J.'s limited document description in Metz v. Breland, ${ }^{35}$ apparently agreeing that its prime purpose is to enable the court to identify the

(1992), 135 A.R. 21 (C.A.) [hereinafter Syncrude Canada].

lbid. at 21-22.

(1991), 80 Alta. L.R. (2d) 169 (Q.B.). (For an analysis of this decision, see supra note 22 at 1112 13).

Roy v. Krilow, supra note 11 at 276.

Ibid.

(1990), 78 Alta. L.R. (2d) 217 (Côté J.A., sitting in Q.B.). (For a discussion of this decision, see supra note 22 at $1111-12$ ). 
documents to be produced for inspection. The types of descriptions suggested in Taylor v. Batten and in Metz v. Breland certainly would not enable the court to receive helpful argument from a party opposing a claim of privilege. It might also be questioned whether a party would meet the onus of proof required to establish privilege imposed by Côté J.A. in Pocklington Foods by, for example, stating that a sealed bundle of documents numbered and initialled by the deponent were prepared for the dominant purpose of instructing counsel for litigation (unless, of course, simply deposing to the basis upon which privilege is claimed will suffice, which is Cotton L.J.'s approach).

The Pocklington Foods decision highlights the continuing tension between, on the one hand giving meaningful protection to privilege by allowing parties to keep confidential particulars of documents they do not wish to disclose, and on the other hand facilitating a meaningful challenge to generic claims of privilege in which the deponent effectively asks the opposite party to trust his determination of which documents are privileged and which are not. Perhaps the best resolution of this issue is that proposed by Kent J. in Roy v. Krilow: as a general practice, a description of documents beyond simply referring to numbered and initialled bundles should be given, with the recognition that the description need not include details which would reveal privileged information. For example, in most cases a party should not be required to disclose the names of witnesses from whom it has received privileged statements, ${ }^{36}$ or the names and disciplines of experts (before disclosure is required under r. 218.1) which might disclose a tactical approach to the lawsuit.

\section{SCOPE OF PRIVILEGE}

There have been a number of authorities which continue to review and define the scope of privilege, particularly as it relates to contemplation of litigation. In Gilchrist v. Oatway ${ }^{37}$ a diary prepared by a plaintiff after a motor vehicle accident was found to be privileged, as the plaintiff's motive in starting the journal was to prepare for a lawsuit. It was not a prerequisite to finding such privilege that the diary be prepared on the instruction of counsel. Videotaped recordings of a plaintiff under surveillance, taken by an investigator hired by the defendant, were confirmed as privileged in $M c D o n n e l l$ v. Lopuch, ${ }^{38}$ and it was further found that the defendant was not required to have its privilege "whittled away"39 by answering questions about subject matter, dates, and details of the surveillance. ${ }^{40}$ Finally, it has now been determined ${ }^{41}$ that section 142

In Caskey v. Guardian Insurance Co. of Canada (1994), 148 A.R. 251 at 264 (Master), Funduk M.C. required the defendant to properly identify privileged witness statements, without disclosing their contents and apparently without compelling disclosure of the witnesses' names. The questions which the defendant was directed to answer related to the number of statements, their dates and who took them.

(1993), 7 Alta. L.R. (3d) 407 (Master).

lbid. at 407.

An approach similar to that in McDonnell v. Lopuch was taken in Auchstaetter v. Froese, [1995] 4 W.W.R. 716 (Sask. Q.B.), where Laing J. carefully reviewed the authorities and held that the plaintiff was entitled to know only the time and place of the surveillance. 
of the Workers' Compensation Act, ${ }^{42}$ which makes the documents of the Workers' Compensation Board privileged and not admissible in evidence in any action without the Board's consent, does not apply in cases where the Board is a party - most typically, in cases where the Board is claiming through another plaintiff pursuant to its subrogated interest. ${ }^{43}$

\section{E. LOSS OF PRIVILEGE}

Finally, the Court of Appeal has confirmed in two recent decisions ${ }^{44}$ that privilege can be waived only by actions of the client (not errors by its solicitors or other agents), and that mere inadvertence will not suffice to waive privilege.

\section{DISCOVERY BY EXAMINATION OF WITNESSES}

\section{A. WHO MAY BE EXAMINED}

Rule 200(1) permits examination of a number of persons, namely, a party to an action, the officer of a corporate party, and present and former employees of a party who appear to have relevant knowledge obtained by virtue of such employment. A corporate party is examined by its selected officer, pursuant to $r$. 214. Where the party is a partnership, any of the partners may be examined as the party pursuant to r. 201 . Similarly, that rule deems a person for whose benefit an action is prosecuted or defended to be a party for purposes of the discovery rules.

As a result of rr. $200(1)$ and 214 , when a corporate party is examined, the opposite party may examine the officer produced to give evidence binding on the corporation, but will also be entitled under r. 200(1) to examine other officers (as well as present and former employees) "who appear to have some knowledge touching the question at issue." Despite the broad wording of the rule, however, the courts have imposed limits on which officers will be subject to examination under this rule. ${ }^{45}$ In BTK Holdings Ltd. v. Greater Edmonton Development Corp. ${ }^{46}$ it was held that a corporate solicitor employed by a party was not "an officer ... in any permissible sense" within the meaning of $r$. $200(1) .^{47}$ The Court's main concern was that corporate solicitors possess privileged information. Even though some of their information may be non-privileged, there are difficulties in keeping privileged information separate, and therefore where a person acts solely in his capacity as solicitor, he will not be subject to discovery as an "officer" under r. 200.

\section{S.A. 1981 , c. W-16.}

The Board's right of subrogation is provided in $\mathbf{s .} 17$ of the Workers Compensation Act. Where the Board is not a party, s. 142 prevents a court from directing production, but still imposes upon the Board a duty to act fairly in deciding whether to permit disclosure. See Jahnke v. Wylie, supra note 41.

Royal Bank of Canada v. Lee and Fishman (1992), 127 A.R. 236 (C.A.); and Syncrude Canada, supra note 30 .

For a general discussion of these limits, see supra note 22 at 1105-06.

(1992), 95 D.L.R. (4th) 573 (Alta. C.A.).

Ibid. at 575, citing Bell v. Klein (1954), 13 W.W.R. 193 (B.C.C.A.). 
The question of spousal privilege was addressed in Chalmers v. Associated Cabs $L t d .{ }^{48}$ where r. 200(1) was relied upon in respect of the examination of the wife of a personal plaintiff, in her capacity as an employee who had worked as the plaintiff's bookkeeper. McMahon J., noting that the scope of discovery in Alberta is wide-ranging, held that the wife could be discovered as an employee; and further, that the scope of the discovery of an employee could embrace all of the person's knowledge touching the matters at issue - even though some of that knowledge might have been gained outside of the employment. In other words, the requirement that an employee appear "to have some knowledge touching the question at issue" is a criterion in choosing the employees subject to examination, but does not restrict the scope of the examination. In Chalmers, however, the scope of the examination was limited by the statutory spousal privilege in the Alberta Evidence Act, which provides as follows:

8. A husband is not compellable to disclose any communication made to him by his wife during the marriage nor is a wife compelled to disclose any communication made to her by her husband during the marriage. ${ }^{49}$

McMahon J. held that the broad scope of r. 200 did not override the spousal privilege, and accordingly, the wife was not required to answer questions about what her husband had communicated to her concerning the accident which was the subject of the lawsuit.

While the courts have recognized the broad scope of discovery under r. 200, an attempt to extend the right of discovery to advisers and consultants was unsuccessful in Trizec Equities Ltd. v. Ellis-Don Management Services Ltd. ${ }^{50}$ The action concerned a claim for losses said to have arisen from soil problems during the excavation of an office building. The plaintiff had retained a consulting company to prepare its delayed occupancy claim, and a geotechnical engineer to act as an adviser on the project when the soils problems arose. Moore C.J.Q.B. referred to Cana Construction Co. v. Calgary Centre for Performing Arts, ${ }^{51}$ where r. 200 was extended to an unpaid volunteer, and Simpson's Num Ti Jah Lodge Ltd. v. Lange, ${ }^{52}$ where a solicitor acting as agent for a party had been the person with virtually sole responsibility for negotiating a contract. Those cases were distinguished on the basis that "the connection between the company and the individual was significant and went beyond the mere contractual relationship, [and on the basis that] ... the individuals performed functions broadly equivalent to those performed by traditional officers and employees." ${ }^{53}$ On the other hand, in the case before him, Moore C.J.Q.B. held that the geotechnical engineer was retained as a consultant, and the loss specialists were "arm's length parties engaged to provide professional services." ${ }^{54}$ These individuals all had knowledge touching questions and issues, but it had been acquired in their capacity as consultants. The Court expressed a concern about unduly expanding the number of people who could be examined:

(1994), 152 A.R. 306 (Q.B.) [hereinafter Chalmers].

R.S.A. 1980, c. A-21, s. 8.

(1994), 19 Alta. L.R. (3d) 433 (Q.B.) [hereinafter Trizec].

(1986), 71 A.R. 158 (Q.B.).

(1991), 83 Alta. L.R. (2d) 169 (Q.B.).

Trizec, supra note 50 at 437.

Ibid. at 433. 
If an application of this kind was permitted, it would open the floodgates to the extent that it would be difficult to refuse similar applications for the right to discover any consultant or any subcontractor.

The connection between an individual and a corporate party must surely be more than simply a contractor arm's length relationship. The hiring of a party or a company as a consultant does not make them an officer subject to examination for discovery. ${ }^{55}$

In short, the fact that a party's engagement of consultants may prevent discovery of facts which would normally be available if the work were performed by corporate officers or employees does not justify expanding the scope of persons subject to examination. Moore C.J.Q.B. accepted the fact that our rules have been framed to restrict pre-trial examinations to persons having a close association with the parties to the lawsuit, in contrast to the wide range of persons subject to examination in some other jurisdictions.

\section{B. COMPELLING ATTENDANCE}

In arranging examinations for discovery, issues arise over the proper place at which to conduct examinations and the compellability of witnesses who reside out of the jurisdiction.

It has been held that r. 200(1), which authorizes an examination "whether the party or person is within or without the jurisdiction," permits the conduct of examinations outside the province. Rule 203(3) requires discoveries to be held before an examiner, but that rule can be read as allowing the court to appoint an out-of-province examiner. In determining whether to permit a discovery out of the province, the test to be applied is what would be "just and convenient in the circumstances," and the paramount consideration will be the convenience of the parties. These principles were recently applied in Paterson v. Hamilton ${ }^{56}$ by O'Leary J. (as he then was), who directed that examinations be conducted in Denver, Colorado, where an individual defendant had numerous business and civic responsibilities. He ordered that the additional disbursements of the examining parties and their counsel would be paid by the defendants who had requested the foreign examination. (The defendants, in making their application, had undertaken to pay such costs.)

Different considerations apply, of course, when the examining party seeks to discover a non-party, such as a former employee of a party, who lives outside of the jurisdiction and does not voluntarily submit to an examination. There have been recent cases reaching different conclusions on the compellability of such a witness for discovery and neither decision referred to the other. Forsyth J., in Suncor Inc. v. Canada Wire \& Cable Ltd. ${ }^{57}$ allowed an application to the court for an order requesting an Ontario court to assist in the examination for discovery of an ex-employee. The request was to 
be made under Ontario's Evidence Act, ${ }^{58}$ which provided for court assistance upon receipt of an appropriate request for examination of a witness. Forsyth J. also noted that r. 200 specifically contemplates examination of a person who is outside of Alberta. By contrast, in Cambridge (next friend of) v. Traff, ${ }^{59}$ the examining party sought a subpoena under the Interprovincial Subpoena $A c^{60}$ to compel an out-of-province witness to submit to an examination for discovery. Smith J. interpreted the statute as applying only to subpoenas for evidence required during a proceeding "in court," which was supported by authorities interpreting a similar provision in British Columbia. Accordingly, he held that the statute did not authorize issuance of subpoenas for examinations for discovery, which was found by Smith J. to be regrettable in light of the importance of discovery in modern litigation. (An important difference in the Cambridge case is that the witness resided in Manitoba. While the point is not addressed in the decision, Manitoba's Evidence $A c t^{61}$ does not have a provision such as the one from Ontario which Forsyth J. relied upon in the Suncor case).

\section{RE-EXAMINATIONS}

It is customary for examining parties to reserve their right to a further examination of the opposite party on matters arising from undertaking responses, employees' evidence, and production of new documents. In addition, the defendants often request further examinations of the plaintiff before trial, to ensure that they have current discovery evidence, particularly in personal injury and wrongful dismissal actions.

However, defendants are not entitled as of right to a second discovery. In Rudovics v. Misericordia Hospital, ${ }^{62}$ Veit J. made the following observations:

There is, of course, power in the court to allow a second discovery of a party. Nonetheless, this discretion must be exercised judicially; second discoveries, merely for up-dates, should not be allowed as a matter of course. The defendants choose the timing of the plaintiff's discovery; they should normally be bound by the decision they make about that. ${ }^{63}$

In the case before her, no specific reason apart from the passage of time had been given by the defendants for requiring further discovery, and their request was therefore denied by the Court. ${ }^{64}$

A court's reluctance to enforce requests for further discoveries appears in other jurisdictions as well. In Ontario, it has been held that an adverse party has a right to compel re-attendance only where the party sought to be examined provided information

R.S.O. 1990 , c. E-23.

(1994), 19 Alta. L.R. (3d) 248 (Q.B.) [hereinafter Cambridge].

S.A. 1981 , c. I-8.1.

R.S.M. 1987, c. E-150.

(1994), 150 A.R. 363 (Q.B.).

Ibid. at 365.

See also Reich v. Dewitz (1995), 30 Alta. L.R. (3d) 410 (Master), where Quinn M.C. refused an application for second discovery of an individual party. He reviewed the authorities and expressed the reluctance of courts to permit second examinations. 
(for example, by undertaking response) contrary to what had been provided at the initial examination. Simply giving an undertaking or an answer after discovery did not entitle a further examination. ${ }^{65}$ In Prince Edward Island, the plaintiff in a personal injury action opposed attending for a second discovery because she had disclosed the nature of her injuries and problems when first examined, and the medical reports did not indicate a deterioration in her condition. Accepting those reasons, the Court denied the request for a second discovery, noting that too much leniency in this area "leads to abuse by lawyers of the whole discovery system." ${ }^{16}$

\section{SCOPE OF DISCOVERY}

It is well recognized in Alberta authorities that the scope of discovery is very broad, extending to all inquiries which might directly or indirectly "touch the matters in question. ${ }^{.67}$ The only general limit as to scope has been that questions going only to credibility need not be answered. ${ }^{68}$ There have been some recent affirmations of this principle.

In Rutherford v. Swanson, ${ }^{69}$ the plaintiff claimed damages against a group of defendants which included the Aryan Nations Organization, alleging that he was injured in a racially-motivated assault. The defendant Fuhr was not involved in the assault at issue, but was alleged to have been part of the conspiracy to aid and abet those who committed the physical assault. He admitted in his pleadings to being a racist. He objected to questions which apparently were directed at his participation or support of other acts of racist violence. Biebly J. noted the broad scope of discovery, but observed that it "may be" limited by authority that questions directed at credibility are not proper "unless that is one of the issues in the pleadings or unless the witness himself has placed it in issue." ${ }^{70}$ She further observed that Fuhr may have put his character and credit in issue by his admission to being a racist, but did not decide the issue on that point. She generally permitted the disputed questions to be asked, even though some of them might relate to credibility, because among other things, they were directed at obtaining similar fact evidence. Citing authority, she held that similar fact evidence going to the proof of habit or custom is generally admitted, and found that "acts of racist violence or support for racial violence might go to show Fuhr had an intention and scheme to engage in violence toward the plaintiff." $" 11$ Questions will not be disallowed "unless they relate solely to credibility."

Christie Corp. v. Alvarez (1994), 34 C.P.C. (3d) 92 (Ont. H.C.). It should be noted that in making this ruling, the Court made reference to the Ontario rules providing for examinations by written interrogatories.

Gallinger v. Kurylyk (1994), 33 C.P.C. (3d) 224 at 227 (P.E.I.S.C.T.D.).

The leading authorities, based on r. 200(1), are Czuy v. Mitchell, [1976] 6 W.W.R. 676 at 679 and 680-83 (Alta. S.C.A.D.); Drake v. Overland, [1980] 2 W.W.R. 193 at 203 (Alta. C.A.); and Metz v. Breland, supra note 35 at 219.

Czuy v. Mitchell, ibid. at 681, relying upon Medicine Hat Wheat Co. v. Norris Commission Co. (1916), 10 W.W.R. 1092 at 1099 (Alta. S.C.A.D.). See also Drake v. Overland, ibid.

(1992), 129 A.R. 155 (Q.B.).

Ibid. at 157.

Ibid.

Ibid. 
The rule against questions directed at credibility was the basis for dismissing an application seeking to compel production of information pursuant to undertakings in Yeung v. Yeung. ${ }^{73}$ The plaintiff had commenced a replevin action against her daughterin-law, seeking the return of cash and jewellery alleged to have been stolen. In examinations for discovery, the defendant was examined in relation to her theft convictions and was requested to produce names of doctors and related medical information concerning the defence to charges of theft. Funduk M.C. found the questioning of the defendant to be "an abuse of an examination for discovery" as it was directed solely to credibility and character, which is impermissible where not raised as an issue in the pleadings.

The limits of the rule against questioning on credibility were again tested in a contract dispute which concerned allegations of motive. Otis Canada Inc. v. Owners Condominium Plan 782-0751 $1^{74}$ concerned an elevator maintenance service contract, pursuant to which the plaintiff serviced the defendant's elevators. The defendant stopped paying the plaintiff, and the plaintiff conjectured that this was because it received an offer of better terms from the plaintiff's competitor. The plaintiff therefore sought production of materials related to the arrangement entered into between the defendant and the plaintiff's competitor.

Veit $\mathrm{J}$. held that "it is always relevant in contract proceedings to determine whether a witness may have some special ... bias or interest" which might be relevant to assess past conduct and present testimony. ${ }^{75}$ She then applied that principle to the facts at hand, which would suggest that she found the defendant to have a special bias or interest which would be relevant to a breach of contract action. ${ }^{76}$ Veit J. then found that while motive and bias might be relevant, the court may exercise discretion both at trial and at discovery to limit questioning in this area to avoid, in the words of Wigmore, "multifariousness and a confusion of issues" - that is, to avoid "getting sidetracked."77 She referred to a number of passages in Stevenson and Côté's Civil Practice Guide 1989, establishing that the courts are increasingly allowing questions going to motive, such as questions about why a party broke a contract; and that this latitude extends even where the primary use of motive may be to affect credibility. ${ }^{78}$

In summarizing her conclusions, Veit J. stated that "discovery questions about motive should be limited to obtaining facts and admissions about motives." ${ }^{79}$ In the case before her, she allowed the plaintiff "full reign" to examine the defendant on

(1993), 137 A.R. 303 (Master).

(1992), 126 A.R. 303 (Q.B.).

Ibid. at 304.

It may be questioned, with respect, whether the simple fact that a party has an opportunity to improve their commercial position gives rise to a finding of special bias within the meaning of the authorities cited. Such a "special bias" would apply to virtually every party in a commercial contract dispute.

Supra note 74 at 305.

Ibid. at 305-07, referring to W.A. Stevenson \& J.E. Côté, Civil Procedure Guide, 1989 (Edmonton: Juriliber, 1989).

Ibid. at 307. 
negotiations with the plaintiff's competitor before payments to the plaintiff were stopped, and to inquire about the expected and actual savings received as a result of the new contract. However, she refused to order production of the contract and other documentation.

The Court of Appeal recently affirmed the principle that questions designed to elicit hearsay evidence are admissible at examinations for discovery, even though such evidence may ultimately be inadmissible at trial. Hetherington J.A. held, in Wright v. Schultz, that in some cases, hearsay answers may be admissible at trial if they were adopted by the party being examined. However, obtaining admissions which can be used at trial is not the only purpose of an examination for discovery. Hetherington J.A. observed as follows: "An examination for discovery also has as its goal to enable the party examining to better assess his own case and that of the opposite party. A hearsay answer, even if it is not admissible at trial, may assist in this regard." ${ }^{180}$ It has, therefore, been confirmed that an objection to a discovery question on the ground that it calls for hearsay evidence would not be proper.

Finally, in Jacobson v. Sveen, ${ }^{81}$ the plaintiff brought a personal injury action against her husband (who had driven the car in which she was injured) and the driver of another vehicle. The driver of the other vehicle served a notice to co-defendant under r. 77 on the plaintiff's husband. When the husband was being examined for discovery by the driver of the other vehicle, he refused to answer questions about the health of his wife, the plaintiff, on the ground that there was not an issue concerning the plaintiff's damages between the two defendants. Veit J. held that the questions were proper, on the ground that a litigant in Alberta is entitled to examine on all matters in issue in the action. (She therefore disagreed with the approach taken by Quinn M.C., who had approved British Columbia authority to the effect that the scope of a discovery is restricted to the issues between the examining party and the party being examined. ${ }^{82}$ )

\section{E. DUTY TO INFORM AND UNDERTAKINGS}

There is a well-established practice that selected officers of corporate parties must properly inform themselves to enable the examining party to have an effective discovery. One reason for the practice is that a corporation will have knowledge which arises from sources other than its selected officer - other officers, employees and documents. An effective discovery may require all of this information to be "funnelled" through the selected officer's oral and documentary discovery. As has been observed, our practice of giving undertakings is simply an acknowledgement by a witness that a question is proper, and one that he should answer but for the fact that he has not properly informed himself. ${ }^{83}$ 
It is sometimes questioned whether this principle should be extended to an individual party. The courts, however, have clearly found that individuals have a similar duty to inform themselves. In Wright v. Schultz, Hetherington, J.A. affirmed older Alberta authority ${ }^{84}$ which in turn confirmed English practice, and held that individual parties must inform themselves as to relevant matters from employees, agents and others within a relationship of control, to the extent that their knowledge arose within that relationship. She also confirmed the limitation that a party has no obligation to inquire of a third person over whom he has no control, and gave as examples an employer, someone who has performed medical services for him, and employees at a school he attended. ${ }^{85}$

\section{F. USE OF DISCOVERY EVIDENCE AT TRIAL: GENERAL}

We have noted Hetherington J.A.'s comment in Wright $\mathrm{v}$. Schultz that the use of discovery evidence at trial is only one of the purposes of discovery. However, the rules of how discovery evidence may be used at trial are significant not only for trial practice itself, but also for the proper conduct of the discovery portion of an action. The courts have in recent years provided direction on a number of aspects of reading discovery evidence into the trial record, which will affect how parties conduct their discoveries.

There is initially the basic question of who may read in discovery evidence of a party. It is of course well-established that the party which was examined at discovery cannot use that transcript itself at trial even where the witness has become unavailable. ${ }^{86}$ It has similarly been held that where a party has been examined by one party, another party may not read in the discovery evidence unless counsel have agreed that the transcript is available to parties other than the one conducting the examination. In Hanley v. Ogilvie, ${ }^{87}$ Waite J. applied this rule to prevent the plaintiff from reading in discovery evidence of one defendant which was apparently adduced by another defendant or perhaps a third party at examinations for discovery. As Waite J. phrased it, if there is not an agreement among the parties, "shoot your own bullet if you want to claim the prey."

The result in Hanley v. Ogilvie was based in part on the practice of the profession to enter into agreements permitting use of an examination by another party, and the fact that such an agreement had not been made in that case. The need for such an agreement does not, however, necessarily follow from the applicable rules. The entitlement to examine a party (or officer or employee of a party) is given by r. 200(1) to "any person adverse in interest." The right to use that evidence at trial is given in r. 214(1), which states:

McLean v. Canadian Pacific Railway (1916), 10 W.W.R. 949 (Alta. C.A.); and Medicine Hat Wheat Co. v. Norris Commission Co., supra note 68.

is For this qualification, she cited with approval Tiedemann v. Basiuk (1977), 4 Alta. L.R. (2d) 12 (Q.B.).

86 Paquin v. Gainers Inc. (1989), 71 Alta. L.R. (2d) 74 (C.A.).

87 (1992), 129 A.R. 238 (Q.B.).

$88 \quad$ lbid. at 239. 
Any party to an action or issue may at the trial or on motion use in evidence as against any opposite party any part of the examination of that opposite party, or in case the opposite party is a corporation, of the examination of any officer thereof selected to submit to an examination to be so used.

The rule adopted in Hanley v. Ogilvie effectively holds that every time a new party in a multi-party lawsuit examines a party opposite in interest, it is a separate examination for discovery. In the absence of an express agreement among counsel allowing previous discoveries to be used, every admission must be separately obtained by each party. With respect, it is difficult to see such a result contemplated in r. 214(1), and there seems to be no need for such a principle which is notably different from the practice used when witnesses are examined at trial by different counsel.

The principle that discovery evidence may be used only against the party giving the evidence was confirmed in Syncrude Canada v. Canadian Bechtel Ltd. ${ }^{89}$ Partway through the discovery process, the plaintiffs made "Mary Carter" agreements with the defendants, which left outstanding liability issues to be contested by third parties. A third party sought to read in against the plaintiffs from an examination it had conducted of the defendants, arguing that this would be "just and convenient" because there was now a common interest between the plaintiffs and defendants, and that it might be permitted under r. 214(3). The Court of Appeal rejected this argument, noting among other things that the "Mary Carter" agreement had been made well into the discovery process, and the plaintiffs presumably had no ability to control or influence how the defendants gave their evidence and made their inquiries at discovery. The conclusion was summarized by stating that "it is unfair to put into evidence against a person an admission by a different person, whether or not the two now have similar interests, friendship and cooperation." 90

There has also been recent jurisprudence which should finally put aside the frequent assumption that anything from a party's discovery evidence may be read in, assuming it is placed in its proper context. In Wright v. Schultz, it had been submitted that based on r. 214(1), a trial judge could not exclude any part of an examination which a party opposite in interest chose to read in. As Hetherington J.A. noted, that would mean that questions of admissibility would have to be determined during examinations for discovery rather than at trial. She found that questions of admissibility, even as to discovery evidence, should be determined at trial. Referring to earlier authority, she summarized her view as follows:

It is therefore the responsibility of the trial judge to determine relevance in light of the evidence at the trial. It follows that a trial judge is obliged to exclude from evidence any part of an examination that a party wishes to read which he finds to be irrelevant. Similarly, in my view, it is the responsibility of the trial judge to decide whether evidence is inadmissible for reasons not related to relevancy. He must exclude from evidence any part of an examination that a party wishes to read which he finds to be inadmissible." 
This position best reconciles the broad examination rights during discovery, the entitlement to read discovery evidence into the trial record, and the much more restrictive rules of evidence which apply at trial. As Hetherington J.A. noted, it may be that hearsay evidence, which is properly adduced at discovery, would not be admissible at trial even through the process of reading in discovery evidence.

The frequent dispute over whether a party seeking to read in a discovery passage should also read in other passages was addressed by Veit J. recently, who employed the following test:

[T] he proper test for the assessment of the completeness of a proposed read-in was fairness to the party based on the specific question asked rather than on the topic addressed in the questions. In other words, the objective was not to require the opposing party to read-in everything the examined party said on a topic, but to ensure that the whole answer the party examined gave to a question was read-in.2

In applying this test, she found that it was sometimes necessary for a written undertaking response to be included in the passage sought to be read in.

When discovery evidence has been read in, there is sometimes a question of what effect it has on the party who tendered that evidence as part of its case. The Court of Appeal recently confirmed that a party reading in discovery evidence is taken to adopt it, and must take both its benefit and burden. However, this does not mean that the trial judge is bound to accept the evidence:

However, where, as here, the parties also give evidence at trial, the trial judge is free, as he was here, to exercise his normal function of assessing credibility, finding facts, and reaching conclusions from all the evidence, and is not bound to accept those discovery extracts read in.....3

\section{G. USE OF DISCOVERY EVIDENCE AT TRIAL: EMPLOYEES}

There has, finally, been continuing development of the rules on when the evidence of witnesses other than the selected officer of a corporate party (which might be other current or former officers or employees and are generally simply referred to as "employees") may be read into the trial record. There has been a continuation of the trend which liberalizes the rules that originally seemed designed to prevent reading in employees' evidence except when the reference to it by a selected officer clearly met the common law requirements of an admission - that is, acceptance of the truth of a statement. Prior to Nova, an Alberta Corporation v. Guelph Engineering Company, ${ }^{94}$ it was understood that for an employee's evidence to be read in, it had to be "adopted" by the officer - and an officer had no obligation to specifically accept or reject evidence of an employee which was put to him. Nova v. Guelph seemed to establish that one need only obtain the officer's confirmation that the employee's evidence is information relating to the matters at issue in the lawsuit, as a basis for reading in the 
employee's evidence at trial (which, if not specifically adopted by the officer, could be contradicted by other evidence of the corporation). Even Nova v. Guelph, however, is not the strongest authority, because there had been an agreement among counsel with respect to employees' evidence, and it is unclear what role that played in the decision.

However, in Esso Resources Canada Ltd. v. Stearns Catalytic Ltd., ${ }^{95}$ the court (in a series of interlocutory and trial rulings) adopted the principles applied in Nova v. Guelph, and was required to work out the application of the principles through a number of rulings during the discovery and trial processes.

The first main point established in the interlocutory rulings by Wachowich $\mathrm{J}$. was that a corporate party may not avoid having its employees' evidence read in at trial by refusing to confirm that constitutes evidence of the corporation. This is significant, because before Nova v. Guelph, it was understood that an employee's evidence could never be read in unless it was specifically adopted. That appeared to change as a result of Nova v. Guelph, which would allow the evidence to be read in simply by confirmation that it was information of the corporation, but it would then be subject to being weighed against contrary evidence as it could not be tendered as an admission. It seems that in Esso v. Stearns, an attempt was made to refuse to accept employees' evidence as information of the corporation (much as officers often refused to accept or reject employees' evidence), thereby precluding the evidence from being read in. Wachowich J. dealt with a number of applications concerning whether an officer could be forced to accept the evidence as information of the corporate party, what qualifications could be added, and what the effect of those qualifications would be. Over the series of applications, it became evident that Wachowich J. found it important to give the examining party meaningful discovery of the corporate party, and that meaningful discovery included the right to read in evidence from employees. He found that, as a general rule, a corporate party will be required to confirm that employees' evidence is information of the corporate party, thereby permitting that evidence to be read in at trial. In other words, the courts have effectively mandated the answer which a corporate party must give when asked whether an employee's evidence is information of the corporation.

Over the course of the applications, Wachowich J. also imposed strict limitations on what qualifications could be added by the officer when affirming that the employee's evidence is information of the corporation. In brief, such qualifications must be based on a document or information obtained by the officer from someone on the basis of personal knowledge; they must not go beyond the direct answer to the question asked of the employee; they may not be based on the officer's belief or disbelief of the employee's evidence; and, if the question is so restricted, may not go beyond 
information from the employee in question. ${ }^{96}$ For example, there may be contradictory evidence from another employee, but it would not be proper to qualify the answer by reference to that employee, assuming a properly-worded question. In Wachowich J.'s words:

The memories of one employee may conflict with the memory of other employees or that of the $\mathbf{R}$. 214 officer or may conflict with other information of the corporation. However, the respondent has not been asked about other information it has from other sources. The respondent has been asked whether the information given by a specific employee in response to a specific question is part of the information of the corporation. The applicant is entitled to a simple direct answer, undiluted with supplementary information or assertions of contrary facts. It is entitled to an answer which it can read in at trial as part of its case."

At trial, MacCallum J. dealt with objections against reading in evidence from discovery evidence of employees simply on the basis that it was confirmed to be information of the corporation. MacCallum $J$. further dealt with the effect of qualifications added to the acceptance by the officer of this evidence as corporate information. He found that such evidence was not admissible by virtue of being an admission, because there was no acceptance of the truth of the statements. As to concerns that the employee's statements were hearsay in the officer's mouth, he found that the evidence was not hearsay, but rather "knowledge of the corporation as expressed under oath by an employee and admitted by an officer to be the information of Stearns. ${ }^{.98}$ However, such evidence was rebuttable and, it would appear, subject to "further read-ins at the request of the defendants" as well as other viva voce evidence. ${ }^{99}$

MacCallum J. was careful to add that it will not be permissible to read in any evidence of an employee simply by confirmation that it forms part of corporate information. We again see confirmation of the principle that not everything can be read in to the trial record simply because it comes from a discovery transcript. MacCallum J. stated that he was dealing with employees' statements which would, if given by the employees themselves on the witness stand, be relevant and admissible under the normal rules of evidence. It will be helpful to repeat the order he gave, which contains general guidelines which we may expect to be used in further trials and as guidance for examinations for discovery:

It is, therefore, ordered:

(1) That the plaintiffs may use in evidence, during this trial, as against the defendants, those portions of the Examination for Discovery of each of the defendants' officers; or the written responses provided by the defendants' officers in lieu of Examinations for Discovery, where those officers admit that 
portions of the evidence given by employees and former employees of the defendants at their Examinations for Discovery constitutes some of the information of the defendants.

(2) The information so read in shall be relevant and in the personal knowledge of the employee or former employee.

(3) The information so read in shall have been acquired by the employee or former employee in the normal course of service with the corporation. ${ }^{100}$

The effect of the rulings in Esso v. Stearns is that an examining party is now able to compel a corporate officer to confirm his acceptance of an employee's evidence as corporate information; and if the employee's evidence would be relevant and admissible through the employee on the witness stand, it can be read in at trial as rebuttable evidence against the corporation. Despite MacCallum J.'s comments, there is force in the objections at trial in Esso v. Stearns that what cannot be done directly can now be done indirectly - that is, by going through the proper "hoops" one will virtually always be entitled to read in employees' evidence. The courts have made a policy decision that a litigant is entitled to full discovery of the corporate party; and that such a discovery must include the ability not only to "discover" information and evidence, but also to obtain evidence for the purpose of trial. 